\title{
IMPACTS OF MASTICATION FUEL TREATMENTS ON CALIFORNIA, USA, CHAPARRAL VEGETATION STRUCTURE AND COMPOSITION
}

\author{
Teresa J. Brennan ${ }^{1 *}$ and Jon E. Keeley ${ }^{1,2}$ \\ ${ }^{1}$ US Geological Survey, Western Ecological Research Center, \\ Sequoia-Kings Canyon Field Station, \\ 47050 General's Highway, Three Rivers, California 93271, USA \\ ${ }^{2}$ Department of Ecology and Evolutionary Biology, University of California, \\ 612 Charles E. Young Drive, South Los Angeles, California 90095-7246, USA \\ "Corresponding author: Tel.: +1-406-640-2188; e-mail: tjbrennan@usgs.gov
}

RESUMEN

\begin{abstract}
Mechanical fuel treatments are a primary pre-fire strategy for potentially mitigating the threat of wildland fire, yet there is limited information on how they impact shrubland ecosystems. Our goal was to assess the impact of mechanical mastication fuel treatments on chaparral vegetation and to determine the extent to which they emulate early post-fire succession. Mastication treatments significantly reduced the height and cover of woody vegetation and increased herbaceous cover and diversity. Non-native cover, density, and diversity were also significantly higher in masticated treatments. Comparisons with postfire data from two studies showed that certain ephemeral post-fire endemics were absent or of limited occurrence from masticated plots in comparison to their abundance on adjacent burned plots. Structurally, masticated sites differed in the dense woody debris cover, whereas burned sites had little such ground cover. Regional comparison of masticated plots to previously published post-fire studies found that burned sites had greater cover, densi-
\end{abstract}

Los tratamientos mecánicos de los combustibles representan una estrategia primaria pre-fuego para potencialmente mitigar las amenazas de incendios de vegetación, aunque la información es limitada en relación a cuanto impactan en ecosistemas de arbustales. Nuestro objetivo fue evaluar el impacto de tratamientos de triturado de combustibles sobre vegetación de chaparral y determinar el grado en que los mismos emulan la sucesión temprana post-fuego. Los tratamientos de triturado redujeron significativamente la altura y cobertura de la vegetación arbustiva e incrementaron la cobertura y diversidad de las herbáceas. La cobertura de especies no nativas, su densidad y diversidad fueron también significativamente mayores en los tratamientos de triturado. La comparación con datos post-fuego de dos estudios mostraron que ciertas efímeras endémicas que aparecen post-fuego estuvieron ausentes o muy limitadas en los tratamientos de triturado en comparación con su abundancia en parcelas adyacentes quemadas. Estructuralmente, los sitios que fueron tratados con los tratamientos de triturado, difirieron en su densa cobertura de desechos, mientras que los sitios quemados presentaron muy poca cobertura de estos desechos. La comparación regional entre tratamientos de triturado con estudios previos de post-fuegos demostró 
ty, and diversity of native species. However, masticated sites and burned sites were broadly similar in distribution of different growth forms. Results from our study show that the use of mastication fuel treatments in chaparral are not in alignment with some resource conservation goals, but in some cases it is recognized that such sacrifice of natural resources may be an acceptable tradeoff to potentially mitigating fire hazard. que los sitios quemados presentaron mayor cobertura, densidad y diversidad de especies nativas. Sin embargo, sitios triturados y quemados fueron en general similares en cuanto a la distribución de formas de vida. Los resultados de nuestro estudio mostraron que el uso de tratamientos de triturado en vegetación de chaparral no están en línea con el objetivo de conservación de los recursos, aunque en algunos casos se reconoce que tal sacrificio en recursos naturales puede ser una solución de compromiso aceptable para potencialmente mitigar el peligro de incendios.

Keywords: California, chaparral, fuel treatment effects, invasive species, mastication

Citation: Brennan, T., and J. Keeley. 2017. Impacts of mastication fuel treatments on California, USA, chaparral vegetation structure and composition. Fire Ecology 13(3): 102-120. doi: 10.4996/fireecology.130312013

\section{INTRODUCTION}

Pre-fire fuel reduction treatments have often been used to address the threat of wildfire in many ecosystems around the world (Scott et al. 2014). The complication, however, is that land managers are being tasked with not only mitigating the threat of wildfire but also maintaining ecosystem integrity. Prescribed fire has traditionally been the most common fuel reduction treatment due to its relatively low cost and because of its potential to emulate natural fire disturbances (Ryan et al. 2015), but it has become increasing difficult to conduct due to smoke management regulations, the expanding wildland-urban interface, and lack of community support (Kreye et al. 2014a). Alternatively, mechanical treatments, such as chipping, crushing, and mastication, have become increasingly popular, yet we lack a clear understanding of how these treatments may affect different ecosystems.

Despite efforts to decrease the threat of wildfire through the manipulation of fuels, some fire-prone regions in the world are still experiencing uncharacteristic wildfires (Doerr and Santín 2016). Not only has this intensified the push for more fuel treatments, but it has also led to the development of a variety of specialized techniques and equipment capable of manipulating vegetation in a more cost effective and efficient manner (Vitorelo et al. 2009). Mechanical mastication, in particular, has quickly become one of the most widely used techniques in many forest-dominated and shrub-dominated ecosystems (Kreye et al. $2014 a$ ). It involves the use of a tracked or wheel-based machine with a boom or front-mounted rotating drum or disc to shred live standing woody vegetation. The shredded, or masticated, debris forms a compacted layer of woody fuel on the soil surface, resulting in a fuel structure that is thought to alter fire behavior by reducing flame lengths, intensity, and rate of spread (Kane et al. 2009).

Our current knowledge of masticated fuel treatments comes primarily from a wealth of studies conducted in forested vegetation types, whereas studies in shrubland types are fewer, despite their widespread and increasing use in these systems. A common finding across initial studies characterizing fuels in mixed coni- 
fer forest types of the western USA (Stephens and Moghaddas 2005, Hood and Wu 2006, Battaglia et al. 2010) and in the loblolly forests (Pinus taeda L.) and pine flatwoods of the Southeast (Glitzenstien et al. 2006, Kreye et al. 2014b) was that fuel load and structure were highly variable, and that this variability was due in part to differences in species composition, stand age, pre-treatment site conditions, and machinery used, as well as treatment prescription and desired outcome. Similar results were found in masticated fuel treatments in chaparral of both northern (Kane et al. 2009) and southern California (Brennan and Keeley 2015).

Fire behavior in masticated fuels of many forest types was also found to be highly variable and depended in part on: the total fuel load, depth, and arrangement of masticated debris (Busse et al. 2005, Bradley et al. 2006, Kobziar et al. 2009); the size and shape of masticated particles and their moisture content (Kreye et al. 2011, 2012; Kreye et al. 2013); and the season of burning, as well as the type of fire-wildfire versus prescription burning and heading versus backing (Glitzenstein et al. 2006, Hudak et al. 2011, Knapp et al. 2011). Other studies have shown that fire behavior was influenced by the composition of understory species as well as the elapsed time since the treatment (Kobziar et al. 2009, Kreye and Kobziar 2015).

Our understanding of the impacts of mechanical mastication on recovering vegetation and soils in these treatments, however, is more limited. A few studies have found that shrub recovery in both forested and shrub-dominated systems was greatly influenced by the pre-treatment composition of shrub species and their individual post-disturbance regeneration responses (Kane et al 2010, Potts et al. 2010, Fernández et al. 2015, Fernández and Vega 2016). Differences in species composition and abundance between treated and untreated vegetation have also been observed after mastication treatments, resulting in higher cover, density, and richness of herbaceous plants and, in particular, of non-native annual grasses (Potts and Stephens 2009, Wolk and Rocca 2009, Coulter et al. 2010). The addition of a layer of downed woody fuels on the soil surface has been reported to have a mulching effect on understory plant growth in ponderosa pine (Pinus ponderosa Douglas ex Lawson \& C. Lawson) forests (Wolk and Rocca 2009), as well as a temporary effect on post-treatment soil nitrogen in a variety of mixed conifer forests (Rhoades et al. 2012). When subjected to fire, these downed woody fuels increased soil heating, which often surpassed lethal soil temperatures (i.e., threshold temperatures resulting in the death of living tissue: $40^{\circ} \mathrm{C}$ to $70^{\circ} \mathrm{C}$ for plant tissue, $<100{ }^{\circ} \mathrm{C}$ for bacteria and fungi, and $200^{\circ} \mathrm{C}$ for organic soil matter) when the soils were dry (Busse et al. 2005).

Nevertheless, our present understanding of the effects of mastication in shrublands is still very limited, in particular for the southern California region, which has a diversity of shrub-dominated landscapes. A further complication is that fuels managers within this region have different vegetation management objectives. The goal for one forest, for example, is to permanently type-convert treatment areas along ridgeline fuelbreaks from native shrublands to exotic grasslands, whereas the goal for another is to maintain chaparral in a seral stage across large areal treatments. The goal for natural resource managers, conversely, is to maintain ecosystem integrity, while also ensuring the protection of threatened and endangered species.

The purpose of this study was to address this research gap and to provide information regarding the effects of mastication treatments for both fuels and natural resource managers. We focused on the effects of mechanical mastication on chaparral ecosystems in southern California. Our specific research questions were: 
1. What are the effects of mastication on community structure, diversity, and composition?

2. How do mastication treatments affect the proportions of native and non-native species?

3. How does time since treatment affect community structure and composition?

4. To what extent do mastication treatments emulate early post-fire succession?

\section{METHODS}

\section{Site Description and Experimental Design}

Our research focused on mechanically masticated fuel treatments in shrublands on the Angeles, Cleveland, Los Padres, and San Bernardino national forests of southern California, USA (Figure 1). The climate of the region is mediterranean with mild, wet winters and hot, dry summers, and the topography is rugged and steep with elevations from near sea level to over $3500 \mathrm{~m}$. The rocky and shallow soils of the area are predominantly granitic and support a wide range of shrubland communities that include stands $2 \mathrm{~m}$ to $4 \mathrm{~m}$ in

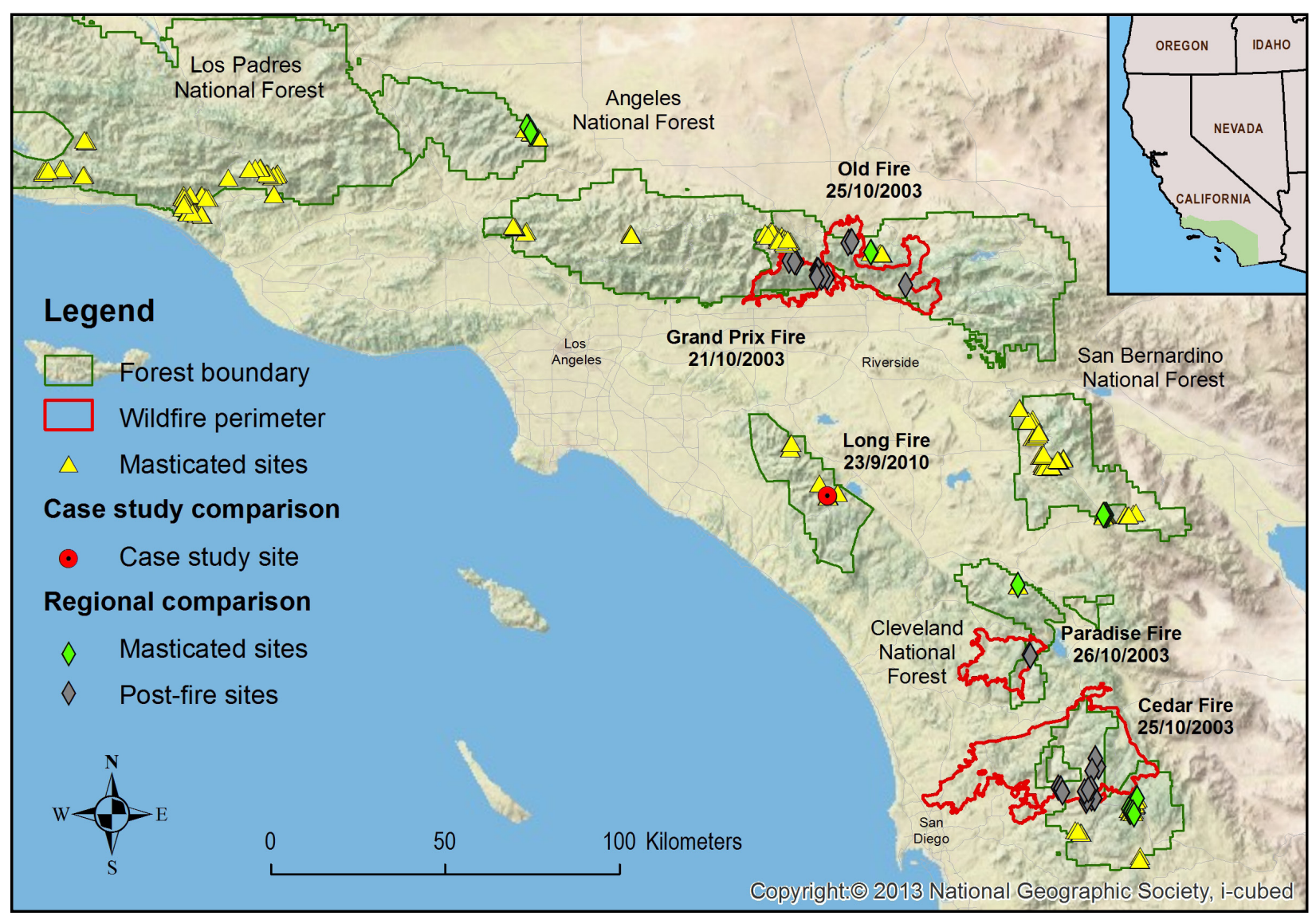

Figure 1. Study site locations of masticated fuel treatments on the four national forests in southern California, USA, surveyed in 2011 to $2012(n=149)$, including a case study comparison between masticated and wildfire plots following the Long Fire in 2010 ( $n=4$ each), and a regional comparison of two-year-old masticated sites surveyed in 2011 $(n=25)$ to two-year-old post-fire study sites established following the 2003 Cedar, Grand Prix, Old, and Paradise fires surveyed in $2005(n=56)$. 
height, dominated by a single species ( $>50 \%$ cover) such as Adenostoma fasciculatum Hook. \& Arn. (chamise), Arctostaphylos spp. Adans. (manzanita), Ceanothus spp. L. (wild lilac), or Quercus spp. L. (oak) and mixed stands without a single dominant.

The masticated fuel treatments that were utilized for this study were identified using the USGS Southern California Fuel Treatment Data Set (http://www.calfiresci.org) and separated into three types: mastication, mastication plus burn, and re-mastication. The size and shape of the available treatments were highly variable; therefore, we used a random sampling design that maximized the number of study sites for each treatment type. We accomplished this by selecting sites from within treatment boundaries using the random-point generator in ArcGIS and a buffer of at least $400 \mathrm{~m}$ between points. Our final sample size of accessible locations included 149 masticated sites, 19 masticated plus burn sites, and 14 re-masticated sites. Detailed comparisons of structural changes between these different treatments were published in a companion paper (Brennan and Keeley 2015). In the present study, we restricted our comparisons to single-entry mastication treatments as the smaller sample sizes of mastication plus burn and re-mastication plots made comparisons of composition and diversity less robust due to the higher variances.

All mastication treatments were completed between 2004 and 2011. They were accomplished using a variety of masticating equipment and ranged in size from less than a hectare to large-scale treatments spanning thousands of hectares across entire ridgelines (Figure 2). The timing of mastication treatments extended across all seasons and ranged in completion time from several days to several years, depending on their size. Stand ages at the time of treatment ranged from $7 \mathrm{yr}$ to 64 $\mathrm{yr}$, and the time between treatment and sampling ranged from $1 \mathrm{yr}$ to $8 \mathrm{yr}$.
In order to evaluate the differences between masticated and early successional post-fire communities, we compared masticated sites to post-fire sites at both a local and regional scale. The first was a local case study on the Cleveland National Forest, where a spark from a masticator ignited a 39-acre wildfire on 23 September 2010 that burned next to the treatment being implemented and comprised similar pre-treatment vegetation. This experiment provided an opportunity to compare masticated and burned sites from the same chaparral community, on the same slope aspect and inclination, and treated at the same time with recovery in the same years. For this comparison, we established four study plots in the masticated treatment and four study plots in the adjacent burned area and monitored them for the first two years following the disturbances.

The second comparison was a regionally broad comparison of all two-year-old masticated sites in this study $(n=25)$ from 2011 to a subset of two-year-old post-fire sites $(n=56)$ from a regional study of early post-fire succession in southern California chaparral in 2005, published in an earlier paper (Keeley et al. 2008). This comparison study investigated factors determining fire severity and ecosystem responses in 250 randomly selected study sites within the Cedar, Grand Prix, Old, and Paradise fire perimeters (Figure 1). All four were high-severity, wind-driven fires that burned in October 2003 when fuel moistures were extremely low. The subset of sites chosen for this regional comparison were based on the criteria that the site was located within one of the four southern California national forests, was in chaparral vegetation, and had a pre-disturbance stand age and elevation within the same range as the two-year-old masticated sites (24 yr to $54 \mathrm{yr}$ and $768 \mathrm{~m}$ to $1507 \mathrm{~m}$ for masticated sites, and $24 \mathrm{yr}$ to $51 \mathrm{yr}$ and $770 \mathrm{~m}$ to $1310 \mathrm{~m}$ for post-fire sites). 


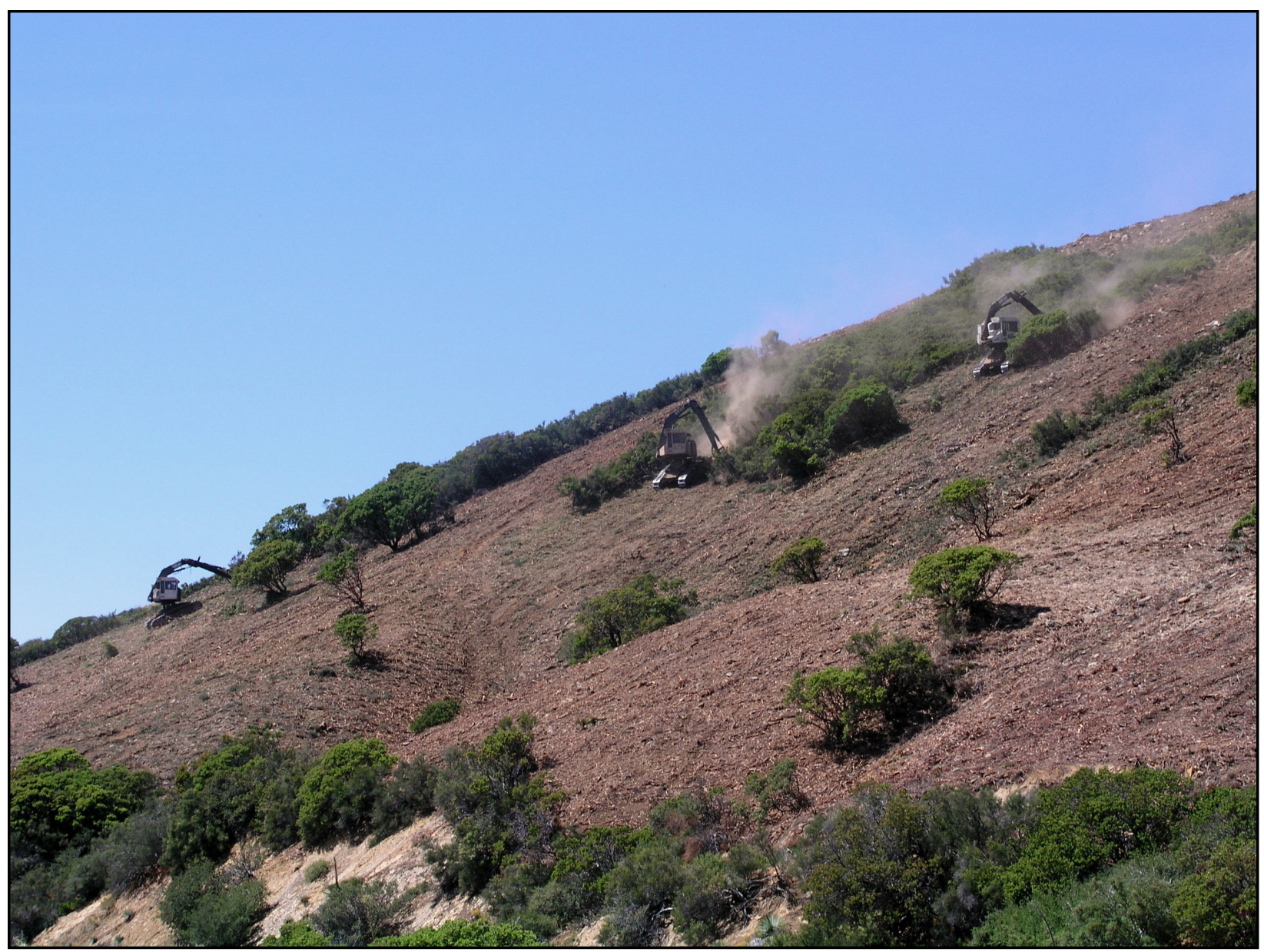

Figure 2. Masticators working in chaparral along the Camino Cielo ridgeline in the Los Padres National Forest of southern California, USA. Photo credit: Fred Montes (2006).

\section{Field Methods}

The sampling design at each masticated study site consisted of a $10 \mathrm{~m} \times 100 \mathrm{~m}$ plot established within the treated area at the random point generated in ArcGIS, and a nearby $10 \mathrm{~m}$ $\times 100 \mathrm{~m}$ control plot placed one meter inside the edge of untreated vegetation to reduce edge affects. Each plot was further subdivided into ten $100 \mathrm{~m}^{2}$ subplots with a nested $1 \mathrm{~m}^{2}$ quadrat placed along the top edge of the measurement tape. Cover and density were recorded for each species within quadrats and a list of additional species present within the rest of the $100 \mathrm{~m}^{2}$ subplot was compiled. Ocular estimates of cover were made and density was either counted or estimated when there were more than 30 individuals in a quadrat. First- year seedlings were recorded separately from mature and resprouting individuals. Comprehensive surveys for additional species were conducted in subplots of treatments, whereas controls had more limited access and were visually inspected from the side nearest the treatment. All plant nomenclature followed Baldwin et al. (2012).

Site variables including aspect, elevation, and slope were recorded for each plot and spatial coordinates were obtained from a global positioning system. Stand height was determined by averaging the heights of the first live woody species encountered along each $10 \mathrm{~m}$ subplot, and pre-treatment stand age was obtained from stem samples collected from the first two obligate seeding individuals encountered in untreated controls (Keeley 1993). All 
mastication data were collected in spring and summer 2011 and 2012.

The sampling design of post-fire study sites from the regional study of post-fire succession (Keeley et al. 2008) consisted of a $20 \mathrm{~m} \times 50 \mathrm{~m}$ plot established within the burn perimeter that was further subdivided into ten $100 \mathrm{~m}^{2}$ subplots with a nested $1 \mathrm{~m}^{2}$ quadrat placed in each corner. Species richness, cover, and density data were collected from each $10 \mathrm{~m}^{2}$ subplot using the same methodology as described above for masticated plots, as was pre-fire stand age data. All wildfire data used in the regional comparison were collected from two-year-old post-fire sites in summer 2005.

\section{Statistical Analyses}

Vegetation characteristics of cover, density, and richness by status (native versus non-native) and vegetative life form (annual, herbaceous perennial, suffrutescent, subshrub, and shrub) were summarized for each plot, and descriptive statistics were calculated for masticated treatments, wildfire, and controls. Paired $t$-tests were used to statistically determine significant differences between controls and masticated treatments $(P<0.05,2$-tailed $)$, and analysis of variance (ANOVA) was used to compare masticated sites to wildfire sites for both the case study and regional comparisons $(P<0.05,2$-tailed $)$. Data assumptions of normality and equal variance were tested using Shapiro-Wilk and Levene's tests, respectively, and when necessary, data were log or squareroot transformed to meet those assumptions. In several instances in which the data could not be transformed to meet the assumptions of a paired $t$-test, we used the Wilcoxon SignedRank test. This was necessary when comparing the cover and density of non-natives, annuals, herbaceous perennials, suffrutescents, and subshrubs between controls and treatments as well as when comparing the richness of suffrutescents and subshrubs. Bivariate regression analyses were conducted using the ordi- nary least squares model to determine if the time elapsed since treatment had an effect on vegetation characteristics $(P<0.05)$, and Jaccard's Index was used to compare community diversity between masticated and wildfire sites in both the case study and regional comparisons (Krebs 1999).

\section{RESULTS}

\section{Untreated Vegetation Structure and Composition}

Vegetation in controls was composed primarily of woody plant species that were typically just over two meters tall and formed a nearly continuous plant cover. Shrubs were the dominant life form, comprising $84 \%$ of the cover (Table 1). There were 52 species in 21 plant families, although over $75 \%$ of the shrub cover and density was from just six species; two obligate resprouters, Cercocarpus betuloides Nutt. and Quercus berberidifolia Liebm.; two obligate seeders, Ceanothus crassifolius Torr. and C. greggii A. Gray; and two facultative seeders, Adenostoma fasciculatum and Arctostaphylos glandulosa Eastw. Smaller woody life forms, which included subshrubs and suffrutescents (woody species that die back to ground level each year), accounted for $7 \%$ of the cover, two-thirds of which was Eriogonum fasciculatum Benthe., Eriophyllum confertiflorum (DC.) A. Gray, and Salvia mellifera Greene. As is typically the case in undisturbed chaparral, herbaceous plants comprised only a fraction of the total cover but were widely scattered in the understory and small openings of $45 \%$ of the plots. Native species dominated 10:1 over non-natives.

\section{Mastication Treatments}

Masticated sites had significantly less live cover than untreated chaparral, but density and species richness were substantially higher (Table 1). Another structural difference was that live plants on masticated sites were only half 
Table 1. Cover (percentage of ground surface covered), density (number of plants per $1000 \mathrm{~m}^{2}$ ), and richness (number of species per $1000 \mathrm{~m}^{2}$ ) of native and non-native plant species and life forms in controls (Cont) and masticated (Mast) fuel treatments $(n=149)$ in southern California, USA, chaparral (2011 to 2012).

\begin{tabular}{|c|c|c|c|c|c|c|c|c|c|}
\hline & \multicolumn{3}{|c|}{ Cover } & \multicolumn{3}{|c|}{ Density } & \multicolumn{3}{|c|}{ Richness } \\
\hline & Cont & Mast & $\boldsymbol{P}$ & Cont & Mast & $\boldsymbol{P}$ & Cont & Mast & $P$ \\
\hline Total & 1 & 11 & $<0.001$ & 7983 & 34516 & $<0.001$ & 10 & 33 & $<0.001$ \\
\hline Native & 92 & 53 & $<0.001$ & 4895 & 11430 & $<0.001$ & 10 & 28 & $<0.001$ \\
\hline Non-native & 1 & 7 & $<0.001$ & 3087 & 23086 & $<0.001$ & 1 & 6 & $<0.001$ \\
\hline Shrubs & 84 & 35 & $<0.001$ & 3163 & 2799 & $<0.001$ & 6 & 8 & $<0.001$ \\
\hline Subshrubs & 5 & 7 & 0.095 & 254 & 796 & $<0.001$ & 1 & 3 & $<0.001$ \\
\hline Suffrutescents & 2 & 6 & $<0.001$ & 356 & 1077 & $<0.001$ & 1 & 3 & $<0.001$ \\
\hline Herbaceous perennials & 1 & 2 & 0.006 & 483 & 1095 & $<0.001$ & 1 & 6 & $<0.001$ \\
\hline Annuals & 1 & 11 & $<0.001$ & 3727 & 28749 & $<0.001$ & 1 & 14 & $<0.001$ \\
\hline
\end{tabular}

as tall as undisturbed chaparral $(2.3 \mathrm{~m}$ versus $1.1 \mathrm{~m}, P<0.001)$. Shrub cover and density were substantially lower in masticated sites, whereas suffrutescents and herbaceous species had more than twice the cover, density, and richness found in controls. Non-native species were also significantly more abundant in masticated treatments versus controls.

Species richness across masticated treatments was over three times the richness in controls and included 447 species from 61 families. The widespread facultative seeder Adenostoma fasciculatum was the most frequently encountered shrub, with similar densities between controls and treatments, because most of these masticated shrubs resprouted (Table 2). Other facultative seeders showed a similar pattern. Obligate seeders, on the other hand, did not resprout after mastication and seedling recruitment was highly variable, hence the three most abundant of these species had less than half of the densities observed in controls. The cover of resprouting species was less than half of the cover found in controls; however, for the obligate seeders, the cover was an order of magnitude lower (data not shown).

While shrubs had a density that was the same or lower in masticated treatments versus untreated chaparral, most other growth forms were more abundant (Table 2). The subshrub Salvia mellifera was equally present on con- trols and masticated sites but, due to seedling recruitment, there was over twice the density in sites that were treated. Other subshrubs such as Eriogonum fasciculatum and Hazardia squarrosa (Hook \& Arn.) Greene were poorly represented in undisturbed chaparral, yet had over five times the density on masticated sites. Suffrutescents followed a similar pattern.

Herbaceous species, however, exhibited the most marked differences in abundance between masticated treatments and untreated chaparral (Table 2). Herbaceous perennials were present in masticated plots by resprouts from bulbs and corms, which were commonly dormant in the understory of the chaparral, whereas annuals had densities that were more than an order of magnitude higher than those observed in controls. Cryptantha spp. Lehn. ex G. Don were the most abundant native species in treated plots. The most abundant species overall, however, were non-native Bromus spp. L. and Festuca spp. L. Non-native species were present in $91 \%$ of masticated plots, in comparison to $33 \%$ of controls.

\section{Masticated Sites over Time}

It was not surprising that eight-year-old masticated treatments had a shrub cover and height that were approaching levels found in untreated stands (Figure 3). Smaller woody plants were still abundant with nearly twice the 
Table 2. Presence (percentage of samples) and density (number of plants per $1000 \mathrm{~m}^{2}$ ) of abundant taxa in controls (Cont) and masticated (Mast) fuel treatments $(n=149)$ in southern California, USA, chaparral (2011 to 2012). Recruitment is facultative seeding (FS), obligate resprouting (OR), or obligate seeding $(\mathrm{OS})$; status is native $(\mathrm{N})$ or non-native $(\mathrm{NN})$.

\begin{tabular}{|c|c|c|c|c|c|c|}
\hline \multirow{2}{*}{ Species (total species richness) } & \multirow[b]{2}{*}{ Recruit } & \multirow[b]{2}{*}{ Status } & \multicolumn{2}{|c|}{ Presence } & \multicolumn{2}{|c|}{ Density } \\
\hline & & & Cont & Mast & Cont & Mast \\
\hline \multicolumn{7}{|l|}{ Shrubs $($ Cont $=52$, Mast $=69)$} \\
\hline Adenostoma fasciculatum & FS & $\mathrm{N}$ & 89 & 93 & 1256 & 1066 \\
\hline Arctostaphylos glandulosa & FS & $\mathrm{N}$ & 46 & 50 & 362 & 358 \\
\hline Arctostaphylos glauca Lindl. & OS & $\mathrm{N}$ & 21 & 22 & 87 & 17 \\
\hline Ceanothus crassifolius & OS & $\mathrm{N}$ & 44 & 38 & 290 & 156 \\
\hline Ceanothus greggii & OS & $\mathrm{N}$ & 37 & 45 & 214 & 64 \\
\hline Ceanothus leucodermis Greene & FS & $\mathrm{N}$ & 14 & 30 & 47 & 72 \\
\hline Cercocarpus betuloides & OR & $\mathrm{N}$ & 37 & 48 & 201 & 207 \\
\hline Quercus berberidifolia & OR & $\mathrm{N}$ & 46 & 50 & 197 & 98 \\
\hline All remaining species & & & & & 509 & 761 \\
\hline \multicolumn{7}{|l|}{ Subshrubs $($ Cont $=14$, Mast $=26)$} \\
\hline Eriogonum fasciculatum & FS & $\mathrm{N}$ & 28 & 62 & 52 & 254 \\
\hline Hazardia squarrosa & OR & $\mathrm{N}$ & 7 & 24 & 8 & 93 \\
\hline Salvia mellifera & FS & $\mathrm{N}$ & 24 & 28 & 126 & 292 \\
\hline All remaining species & & & & & 68 & 157 \\
\hline \multicolumn{7}{|l|}{ Suffrutescents $($ Cont $=19$, Mast $=27)$} \\
\hline Acmispon glaber (Vogel) Brouillet & OS & $\mathrm{N}$ & 9 & 48 & 21 & 291 \\
\hline Eriophyllum confertiflorum & FS & $\mathrm{N}$ & 30 & 54 & 254 & 383 \\
\hline Galium spp. L. & OR & $\mathrm{N}$ & 27 & 79 & 61 & 191 \\
\hline Penstemon spectabilis Thurb. ex A. Gray & OS & $\mathrm{N}$ & 6 & 25 & 4 & 50 \\
\hline Solanum xanti A. Gray & FS & $\mathrm{N}$ & 6 & 32 & 10 & 136 \\
\hline All remaining species & & & & & 30 & 81 \\
\hline \multicolumn{7}{|l|}{ Herbaceous perennials $($ Cont $=37$, Mast $=113)$} \\
\hline Erigeron foliosus Nutt. & OR & $\mathrm{N}$ & 3 & 17 & 151 & 92 \\
\hline Marah macrocarpa (Greene) Greene & OR & $\mathrm{N}$ & 26 & 47 & 51 & 52 \\
\hline Melica imperfecta Trin. & OR & $\mathrm{N}$ & 16 & 26 & 74 & 264 \\
\hline Stipa lepida Hitchc. & OR & $\mathrm{N}$ & 13 & 19 & 75 & 117 \\
\hline All remaining species & & & & & 108 & 515 \\
\hline \multicolumn{7}{|l|}{ Annuals $($ Cont $=55$, Mast $=212)$} \\
\hline Cryptantha spp. & OS & $\mathrm{N}$ & 16 & 94 & 74 & 1271 \\
\hline Festuca octoflora Walter & OS & $\mathrm{N}$ & 1 & 26 & 1 & 989 \\
\hline Pseudognaphalium californicum (DC.) Anderb. & OS & $\mathrm{N}$ & 15 & 53 & 73 & 278 \\
\hline Stephanomeria spp. Nutt. & OS & $\mathrm{N}$ & 3 & 64 & 12 & 278 \\
\hline Bromus diandrus Roth & OS & NN & 5 & 44 & 254 & 309 \\
\hline Bromus madritensis L. & OS & NN & 17 & 70 & 1085 & 4802 \\
\hline Bromus tectorum L. & OS & $\mathrm{NN}$ & 15 & 63 & 1432 & 12974 \\
\hline Erodium cicutarium (L.) Aiton & OS & $\mathrm{NN}$ & 1 & 34 & 1 & 241 \\
\hline Festuca myuros L. & OS & NN & 3 & 49 & 236 & 3384 \\
\hline All remaining species & & & & & 559 & 4223 \\
\hline
\end{tabular}



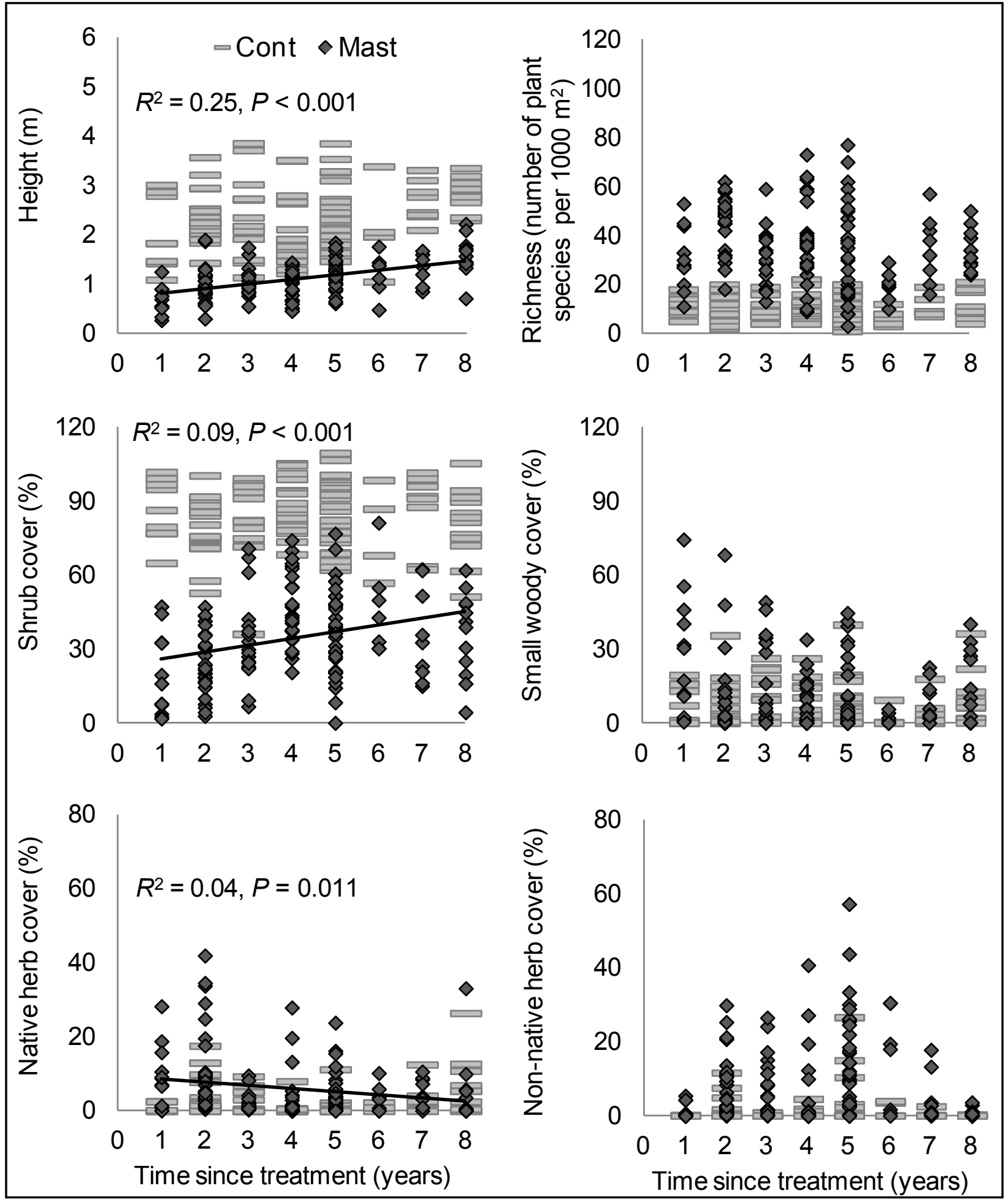

Figure 3. Stand height, richness (number of plant species per $1000 \mathrm{~m}^{2}$ ), and cover (percentage of ground surface covered) of plants in controls (Cont) and masticated (Mast) fuel treatments in chaparral in southern California, USA, by time-since-treatment year $(n=149)$ (2011 to 2012). Trend line included when the relationship was significant $(P<0.05)$. 
cover observed in controls, whereas the cover of native herbaceous species was negatively related to time since treatment, with eight-yearold masticated treatments having nearly the same cover as controls. The cover of non-native herbaceous species, conversely, was not related to time since treatment. Plant density was not related to time since treatment over the given eight-year period $\left(R^{2}<0.00, P=0.993\right.$; not shown) and species richness was still nearly three times higher in eight-year-old masticated treatments than in controls (Figure 3).

\section{Comparison with Early Post-Fire Succession}

Community composition and structure were compared between two-year-old masticated treatments and post-fire chaparral at both a local and regional scale. The local comparison was a burned site directly adjacent to a masticated site, which was at a similar elevation, slope, aspect, and inclination, and appeared to have very similar pre-fire or pre-treatment shrub composition, plus recovery occurred in the same year. A visual illustration of some of the differences in the structure and composition between the two disturbance communities is provided in Figure 4. Structurally, one of the biggest differences was that, on the masticated site, the ground was covered with downed woody debris, whereas on the burned site, fire had consumed all dead surface biomass. In addition, the burned site shows a population of the post-fire endemic species, Ehrendorferia chrysantha (Hook \& Arn.) Rylander (Figure 4b), which was essentially absent from the masticated site (Figure 4a).

Masticated plots of the local comparison site had an average of 22 more species than wildfire plots $\left(F_{1,6}=10.33, P=0.018\right)$, yet the total cover and density of plants in the first post-disturbance year were not statistically different $\left(F_{1,6}=3.90, P=0.096\right.$, and $F_{1,6}=4.75$, $P=0.072$, respectively). By year two, however, masticated plots had an average of $25 \%$ more plant cover $\left(F_{1,6}=19.26, P=0.005\right)$ and nearly five times the density of individuals ob-

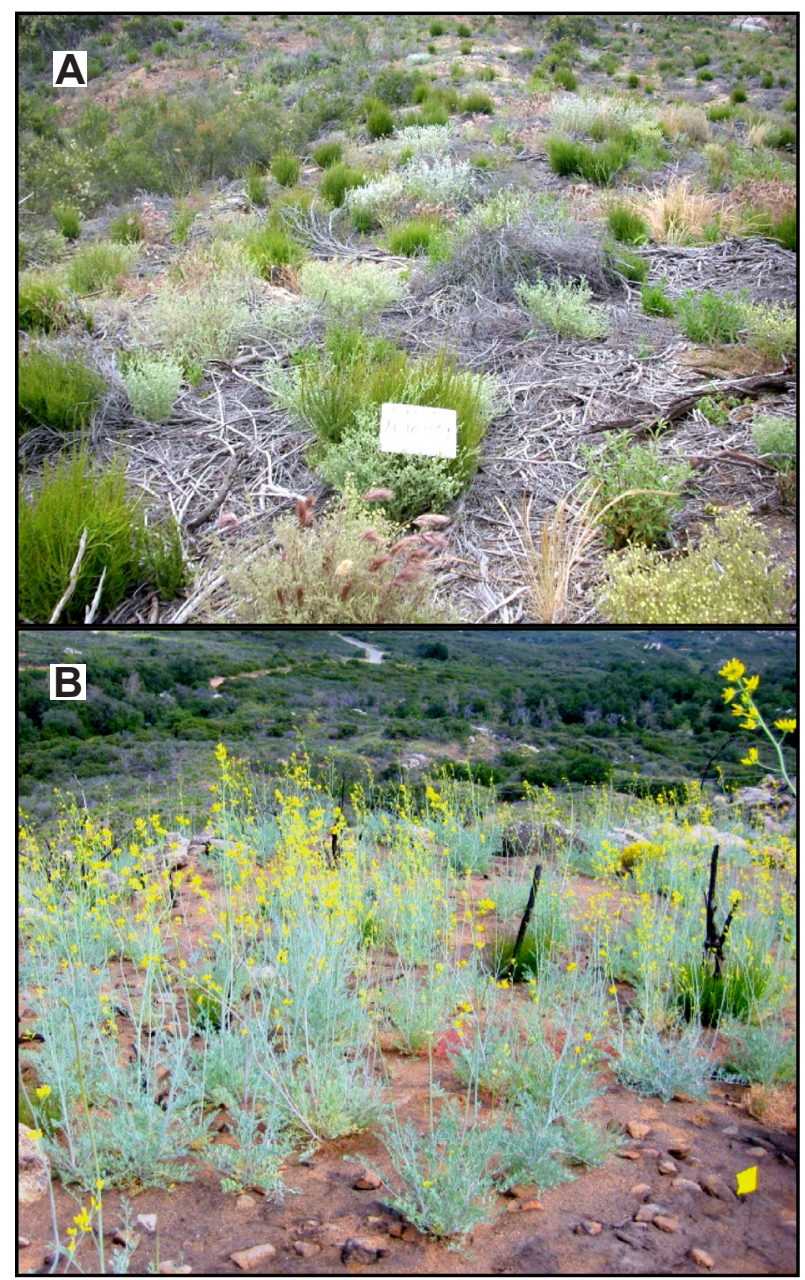

Figure 4. Comparison of a one-year-old masticated treatment plot in chaparral a) to a nearby oneyear-old post-fire plot b) in southern California, USA. Both plots were disturbed on the same day when a spark from a masticator ignited the Long Fire, which burned through untreated vegetation in September 2010. The masticated treatment plot was covered with woody debris, which was absent from the post-fire plot where all dead biomass was consumed by the fire. The post-fire plot was also dominated by Ehrendorferia chrysantha, a postfire endemic, which was absent from the masticated plot only a couple of hundred meters away. Photo credit: Chelsea Morgan (2011).

served in wildfire plots $\left(F_{1,6}=10.57, P=\right.$ $0.017)$. This higher density in masticated plots was largely driven by native and non-native annuals (Figure 5). Community composition was compared with the Jaccard's Index (JI), 


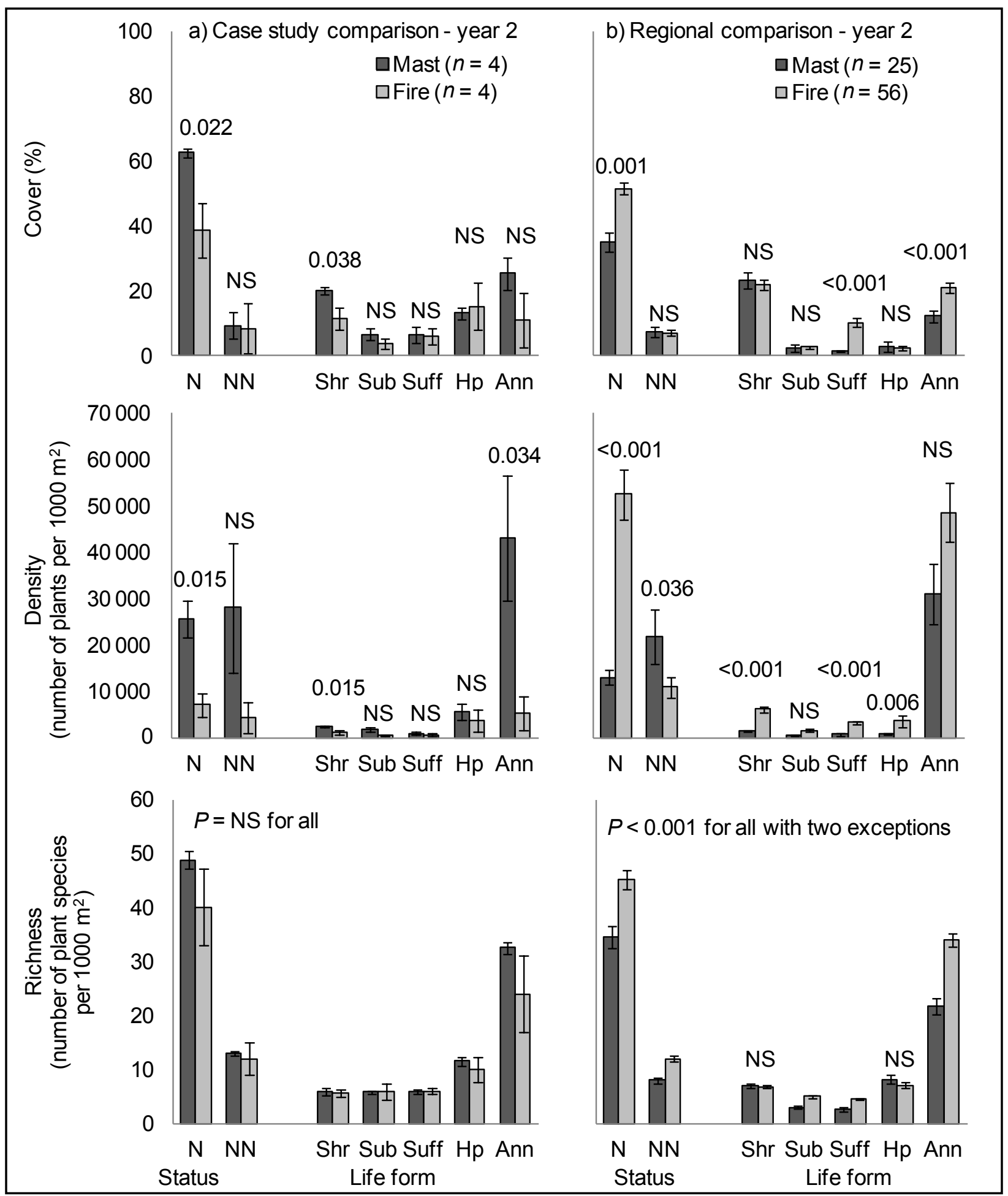

Figure 5. Cover (percentage of ground surface covered), density (number of plants per $1000 \mathrm{~m}^{2}$ ), and richness (number of plant species per $1000 \mathrm{~m}^{2}$ ) of plants by status and life form in two-year-old masticated and wildfire sites in a case study comparison a) and a regional comparison b) in southern California, USA, chaparral (2012). ANOVA results presented for $P<0.05$. Whiskers represent standard error. Ann $=$ annual, $\mathrm{Hp}=$ herbaceous perennial, $\mathrm{N}=$ native, $\mathrm{NN}=$ non-native, $\mathrm{NS}=$ not significant, $\mathrm{Shr}=$ shrub, $\mathrm{Sub}=$ subshrub, Suff = suffrutescent. 
which showed that the masticated and early successional post-fire communities shared only $50 \%(\mathrm{JI}=0.50)$ of the species in year one, and this increased to $63 \%(\mathrm{JI}=0.63)$ in year two. In general, post-fire endemics (e.g., Ehrendorferia chrysantha, Figure 4) were absent or nearly absent from adjacent masticated sites.

The regional comparison of masticated and wildfire disturbances, in contrast to the local comparison, included a mix of different chaparral communities that were not closely matched in location, shrub dominants, stand age, or year of sampling. One of the consistent differences, however, was the significantly greater native cover, density, and species richness on burned sites relative to masticated sites (Figure 5). Native annual species were more widely distributed on post-fire sites than on masticated sites, and several species such as Phacelia cicutaria Greene, Silene coniflora (S. Watson) Otth., and others were largely restricted to burned sites (Table 3). Most non-native annual species were widely distributed on both masticated and burned sites.

\section{DISCUSSION}

The main focus of most mechanical fuel treatments studies has been on their effectiveness in altering fuels and their potential impact on altering fire behavior. However, many resource managers are equally concerned over the impacts of these treatments on native plant communities. In a prior study, we assessed fuel loading and fuel structure by time since treatment on the same masticated sites and found that the rapid recovery of live woody fuels was the primary factor limiting the effectiveness of these treatments in southern California chaparral (Brennan and Keeley 2015). This study is focused on the ecological impact of mastication treatments on community structure and composition. In addition, one of the stated goals of fuels managers on these forests was to maintain chaparral in a young seral stage, and thus we have examined to what extent treated communities resemble early successional post-fire community structure and composition. Lastly, we considered how these changes in community structure might be ex-

Table 3. Presence (percentage of samples) of common native and non-native annual species in two-yearold masticated (Mast; $n=25 ; 2011$ to 2012) and wildfire (Fire; $n=56 ; 2005$ ) sites from a regional comparison of southern California, USA, chaparral.

\begin{tabular}{lcclcc}
\hline Native & Mast & Fire & Non-native & Mast & Fire \\
\hline Acmispon strigosus (Nutt.) Brouillet & 28 & 76 & Avena fatua L. & 7 & 67 \\
Allophyllum gilioides (Benthe.) A.D. Grant \& & 45 & 51 & Brassica nigra (L.) W.D.J. Koch & 24 & 68 \\
$\quad$ V.E. Grant & & & & & \\
Camissoniopsis hirtella (Greene) W.L. & 55 & 84 & Bromus hordaceus L. & 24 & 55 \\
$\quad$ Wagner \& Hoch & & & & & \\
Chaenactis artemisiifolia (Harv. \& A. Gray ex & 28 & 52 & Bromus madritensis & 90 & 100 \\
A. Gray) A. Gray & 79 & 91 & Bromus tectorum & 90 & 58 \\
Cryptantha spp. & 38 & 82 & Erigeron bonariensis L. & 34 & 27 \\
Emmenanthe penduliflora (Benthe.) & 34 & 62 & Festuca myuros & 76 & 88 \\
Logfia filaginioides (Hook \& Arn.) & 3 & 80 & Hypochoeris glabra L. & 28 & 83 \\
Phacelia cicutaria & 66 & 68 & Lactuca serriola L. & 83 & 78 \\
Pseudognaphalium californicum & 66 & 90 & Logfia gallica (L.) Coss \& Germ. & 21 & 73 \\
Rafinesquia californica (Nutt.) & 3 & 51 & Schismus barbatus (L.) Thell. & 17 & 43 \\
Silene coniflora & 59 & 78 & Sonchus asper (L.) Hill & 17 & 50 \\
Stephanomeria virgata Benthe. & 59 & 78 & Sonchus oleraceus L. & 31 & 73 \\
Uropappus lindleyi (DC.) Nutt. & & & & &
\end{tabular}


pected to affect the long-term integrity of these particular systems.

\section{Mastication Effects on Community Structure and Composition}

In comparing masticated sites with adjacent controls, the most obvious change in community structure was the very significant reduction in the height and cover of woody plants. Controls were composed of a mix of a few dominant shrub species that formed a nearly homogenous canopy cover, whereas masticated sites had more complex structures that included a higher diversity of species from a variety of different life forms. Initial changes to the structure of shrubs following mastication facilitated a number of significant shifts in the structure and composition of treated communities in comparison to undisturbed chaparral. The newly opened canopy, for instance, allowed sunlight and water to be more evenly distributed across the soil surface, thus many smaller and less common species were able to establish and increase in cover. Masticated sites, in general, had a higher density and diversity of both woody and herbaceous species than controls. The most dominant woody species present in controls, however, typically maintained their dominance in treatments by resprouting and seed germination. However, there were a few interesting exceptions in which mastication significantly increased the cover and density of species such as Hazardia squarrosa and Acmispon glaber. These particular species are common in post-fire communities of chaparral (Keeley et al. 2006) and it appears that they are opportunistic on disturbed sites in general.

The largest change in the composition of species across masticated sites, however, was the substantial increase in the density and diversity of annuals and herbaceous perennials. Annual species are often pervasive and capable of rapidly establishing on newly disturbed sites due to a dormant soil seed bank and a short life cycle (Keeley et al. 2006). They are also extremely efficient at colonizing disturbed areas from offsite seed sources (Keeley et al. 2003). The most dominant herbaceous perennials, on the other hand, tended to be species that resprouted from dormant underground vegetative structures such as bulbs, roots, and rhizomes. Unless their reproductive structures are damaged during the disturbance, species with these adaptations have an initial advantage over perennial species that recruit from seed because they are already established in sites and can more readily compete for the available resources (Keeley et al. 1981).

A substantial proportion of the increased density and diversity of herbaceous plants in masticated treatments was composed of non-native species. Our results were similar to those of Potts and Stephens (2009) who investigated mastication in Adenostoma fasciculatum-dominated chaparral in northern California and found that non-natives accounted for $34 \%$ of the total species richness and $61 \%$ of the total density of all plants combined. In general, the diversity of non-native species was higher in treatments; however, the most common species, which were primarily non-native grasses, were typically found in both treatments and controls. Bromus madritensis and Bromus tectorum, which are known to be aggressive invaders because of their rapid growth, spring maturation, and high seed output (Atkinson and Brown 2016), were the two most abundant non-native species with the highest presence and density in both masticated sites and untreated controls. Centaurea melitensis L. was another invasive species that was present in high densities in about onefourth of treatments and is also of particular concern because of its potential to displace native plants and animals (DiTamoso and Gerlach Jr. 2000).

\section{Comparison of Masticated Sites to Post-Fire Recovery}

Managers have often questioned whether or not the use of mechanical treatments can 
serve as a surrogate for fire in a number of ecosystems (Stephens et al. 2012). In an attempt to answer this question for chaparral, we utilized two comparisons, a local case study and a regional comparison of two-year-old masticated and wildfire sites. The initial effect of both disturbance types was the considerable mortality of shrubs, and we suspect that this is primarily influenced by the severity of the disturbance, whether mechanical or fire. Our local case-study plots, for example, were burned by the Long Fire that started in late September when fuel moistures were particularly low. Most shrubs were burned completely to the ground, causing extensive damage to the resprouting structures of the plants and resulting in high mortality. Shrubs in the masticated plots, in comparison, sustained less damage and were capable of resprouting following the disturbance. These differences would not likely have been as evident if the fire had been less severe. Shrub recruitment, on the other hand, appeared to be influenced by both the type of disturbance and the recruitment traits of individual species. Masticated plots in the regional comparison, for instance, had a significantly lower density of shrubs than the wildfire plots, as well as a considerably lower recruitment of obligate seeding species. Sites that are masticated will generally have a lower potential for seedling recruitment than sites that are burned because a number of obligate seeding species depend on fire-stimulated seed germination, which is absent in masticated sites.

Both mastication and wildfire elicited a substantial increase in the abundance and diversity of smaller woody and herbaceous species. There were differences in the cover, density, and richness of the smaller life forms between the two disturbances that appeared to be scale dependent, yet they both contained most of the same common species. There were, however, certain species such as Phacelia cicutaria, P. brachyloba (Benthe.) A. Gray, and Ehrendorferia chrysantha that were very abundant in early post-fire communities and relatively uncommon in masticated sites. These species are post-fire endemics that require fire cues such as heating or smoke to germinate. The non-native species, on the other hand, were found in abundance in both disturbance types. These species are opportunistic and have a shortened reproductive cycle, a high reproductive output, and well-developed seed dispersal mechanisms (Zouhar et al. 2008), allowing them to establish independent of disturbance type.

Masticated communities do appear to emulate post-fire communities to some extent within the first two years of the disturbance. However, they differ structurally in having a dense layer of dead surface fuels, which is absent on recently burned sites (e.g., Figure 4). The impacts of these structural differences on soil microbial processes, as well as on soil heating during subsequent fires, are in need of further study. Mastication, however, can never fully emulate fire in chaparral systems due to the absence of many ephemeral species that require fire cues to germinate.

\section{Management Implications}

The primary concern regarding the use of mastication treatments, from a resource management standpoint, is the potential for permanent shifts in the structure and composition of communities that can lead to the perpetuation of non-native species and the loss of system integrity. A healthy system that is masticated is most likely capable of recovering a dominant shrub canopy; however, this recovery does not come without potentially negative consequences. The use of these treatments can alter the composition of shrubs and tend to favor facultative seeding species, such as Adenostoma fasciculatum, at the expense of obligate seeding species. This can potentially lead to more single-species dominated stands that are less resilient to future disturbances due to a loss of species with alternative recruitment traits. 
Another consequence of using mastication treatments is the introduction of non-native species, particularly non-native grasses. When chaparral is disturbed by fire, there are temporary changes in the structure and composition of life forms, yet the effects are typically short lived (Keeley et al. 2012). However, if another disturbance event occurs within a short time interval, the changes to the community often persist and become permanent (D'Antonio 2000, Keeley and Brennan 2012). There were no relationships between cover or density of non-native species in masticated sites and the elapsed time since treatment over an eightyear recovery period. The persistence of non-native species is of particular concern in these systems because they have the capacity to alter fire dynamics and can promote the conversion of native woody shrublands to shallow-rooted herbaceous systems (D'Antonio and Vitousek 1992, Keeley et al. 2012). Type conversion from deep-rooted shrubs to shallow-rooted grasses and forbs can affect soil stability, thereby increasing the potential for erosion and debris flow (Spittler 1995).

Another concern about using masticated treatments is the layer of woody debris that is left on site. Decomposition in chaparral is very slow (Parker et al. 2016) and there is an increasingly high likelihood that these treatments will be subjected to a wildfire event before the fuel load from mastication has decomposed. The combustion of an excessive and abnormal woody fuel load on the soil surface in masticated treatments could result in prolonged heating, with temperatures capable of damaging plant structures and killing soilstored seeds (Busse et al. 2005). Thus, if masticated treatments are burned in intense wildfires, the community is more likely to be put on a trajectory towards type conversion.

The threat of wildfire in many regions is still very high despite efforts to treat and manage thousands of acres of vegetation. Results from our study reveal that the use of mastication fuel treatments in chaparral are not in alignment with resource conservation and should only be considered in areas where the loss of natural resources is acceptable to potentially mitigate fire hazard. The primary focus of fuels management has often been the use of extensive mechanical fuel treatments; however, more may be gained by shifting that focus to changes that could be made in other areas including better land use planning, appropriate defensible space, building construction materials, urban vegetation, ignition control, and fire prevention education.

\section{ACKNOWLEDGEMENTS}

We are grateful to C. Morgan, C. Huff, R. Mansfield, G. Dill, A. Baniaga, and W. Reed for their field assistance, and we thank the USFS Angeles, Cleveland, Los Padres, and San Bernardino national forests for their cooperation with this project. Any use of trade, product, or firm names is for descriptive purposes only and does not imply endorsement by the US government.

\section{LITERATURE CITED}

Atkinson, S.Y., and C.S. Brown. 2016. Attributes that confer invasiveness and impacts across the large genus Bromus: lessons from the Bromus REEnet database. Pages 155-186 in: M.J. Germino, J.C. Chambers, and C.S. Brown, editors. Exotic brome-grasses in arid and semiarid ecosystems of the western US: causes, consequences and management implications. Springer International Publishing, Cham, Switzerland. doi: 10.1007/978-3-319-24930-8_6

Baldwin, B.G., D.H. Goldman, D.J. Keil, R. Patterson, T.J. Rosatti, and D.H. Wilken, editors. 2012. The Jepson manual: vascular plants of California. Second edition. University of California Press, Berkeley, USA. 
Battaglia, M.A., M.E. Rocca, C.C. Rhoades, and M.G. Ryan. 2010. Surface fuel loadings within mulching treatments in Colorado coniferous forests. Forest Ecology and Management 260: 1557-1566. doi: 10.1016/j.foreco.2010.08.004

Bradley, T., J. Gibson, and W. Bunn. 2006. Fire severity and intensity during spring burning in natural and masticated mixed shrub woodlands. Pages 419-428 in: P.L. Andrews and B.W. Butler, editors. Fuels management-how to measure success: conference proceedings. USDA Proceedings RMRS-P-41, Rocky Mountain Research Station, Fort Collins, Colorado, USA.

Brennan, T.J., and J.E. Keeley. 2015. Effect of mastication and other mechanical treatments on fuel structure in chaparral. International Journal of Wildland Fire 24: 949-963. doi: 10.1071/ WF 14140

Busse, M.D., K.R. Hubbert, G.O. Fiddler, C.J. Shestak, and R.F. Powers. 2005. Lethal soil temperatures during burning of masticated forest residues. International Journal of Wildland Fire 14: 267-276. doi: 10.1071/WF04062

Coulter, C.T., D. Southworth, and P.E. Hosten. 2010. Prescribed fire and post-fire seeding in brush masticated oak-chaparral: consequences for native and non-native plants. Fire Ecology 6: 60-75. doi: 10.4996/fireecology.0602060

D’Antonio, C., and P.M. Vitousek. 1992. Biological invasions by exotic grasses, the grass/fire cycle, and global change. Annual Review of Ecology, Evolution and Systematics 23: 63-87. doi: 10.1146/annurev.es.23.110192.000431

D’Antonio, C.M. 2000. Fire, plant invasions, and global changes. Pages 65-93 in: H.A. Mooney and R.J. Hobbs, editors. Invasive species in a changing world. Island Press, Covelo, California, USA.

DiTamoso, J.M., and J.D. Gerlach Jr. 2000. Centaurea melitensis. Pages 98-100 in: C.C. Bossard, J.M. Randall, and M.C. Hoshovsky, editors. Invasive plants of California's wildlands. University of California Press, Berkeley, USA.

Doerr. S.H., and C. Santin. 2016. Global trends in wildfire and its impacts: perceptions versus realities in a changing world. Philosophical Transactions of the Royal Society B 371: 3-45. doi: 10.1098/rstb.2015.0345

Fernández, C., J.A. Vega, and T. Fonturbel. 2015. Does shrub recovery differ after prescribed burning, clearing and mastication in a Spanish heathland? Plant Ecology 216: 429-437. doi: 10.1007/s11258-015-0447-y

Fernández, C., and J.A. Vega. 2016. Shrub recovery after fuel reduction treatments in a gorse shrubland in northern Spain. Journal of Environmental Management 166: 211-216. doi: 10.1016/j.jenvman.2015.10.028

Glitzenstein, J.L., D.R. Streng, G.L. Achtmeier, L.P. Naeher, and D.D. Wade. 2006. Fuels and fire behavior in chipped and unchipped plots: implications for land management near the wildland/urban interface. Forest Ecology and Management 236: 18-29. doi: 10.1016/j. foreco.2006.06.002

Hood, S., and R. Wu. 2006. Estimating fuel bed loadings in masticated areas. Pages 333-340 in: P.L. Andrews and B.W. Butler, editors. Proceedings of the conference: fuels management - how to measure success. USDA proceedings RMRS-P-41, Rocky Mountain Research Station, Fort Collins, Colorado, USA.

Hudak, A.T., I. Rickert, P. Morgan, E. Strand, S.A. Lewis, P.R. Robichaud, C. Hoffman, and Z.A. Holden. 2011. Review of fuel treatment effectiveness in forests and rangelands and a case study from the 2007 megafires in central Idaho, USA. USDA Forest Service, General Technical Report RMRS-GTR-252, Rocky Mountain Research Station, Fort Collins, Colorado, USA. 
Kane, J.M., J.M. Varner, and E.E. Knapp. 2009. Novel fuelbed characteristics associated with mechanical mastication treatments in northern California and south-western Oregon, USA. International Journal of Wildland Fire 18: 686-697. doi: 10.1071/WF08072

Kane J.M., J.M. Varner, E.E. Knapp, R.F. Powers. 2010. Understory vegetation response to mechanical mastication and other fuels treatments in a ponderosa pine forest. Applied Vegetation Science 13: 207-220. doi: 10.1111/j.1654-109X.2009.01062.x

Keeley, S.C., J.E. Keeley, S.M. Hutchinson, and A.W. Johnson. 1981. Postfire succession of the herbaceous flora in southern California chaparral. Ecology 62: 1608-1621. doi: $10.2307 / 1941516$

Keeley, J.E. 1993. Utility of growth rings in the age determination of chaparral shrubs. Madroño 40: $1-14$.

Keeley, J.E., D. Lubin, and C.J. Fotheringham. 2003. Fire and grazing impacts on plant diversity and alien plant invasion in the southern Sierra Nevada. Ecological Applications 13: 13551374. doi: 10.1890/02-5002

Keeley, J.E., C.J. Fotheringham, and M. Baer-Keeley. 2006. Demographic patterns of postfire regeneration of mediterranean-climate shrublands of California. Ecological Monographs 76: 235-255. doi: 10.1890/0012-9615(2006)076[0235:DPOPRI]2.0.CO;2

Keeley, J.E., T.J. Brennan, and A.H. Pfaff. 2008. Fire severity and ecosystem responses following crown fires in California shrublands. Ecological Adaptations 18: 1530-1546. doi: 10.1890/07-0836.1

Keeley, J.E., and T.J. Brennan. 2012. Fire-driven alien invasion in a fire-adapted ecosystem. Oecologia 169: 1043-1052. doi: 10.1007/s00442-012-2253-8

Keeley, J.E., W.J. Bond, R.A. Bradstock, J.G. Pausas, and P.W. Rundel. 2012. Fire in Mediterranean ecosystems: ecology, evolution and management. Cambridge University Press, England, United Kingdom.

Knapp, E.E., J.M. Varner, M.D. Busse, C.N. Skinner, and C.A. Shestak. 2011. Behaviour and effects of prescribed fire in masticated fuelbeds. International Journal of Wildland Fire 20: 932-945. doi: 10.1071/WF10110

Kobziar, L.N., J.R. McBride, and S.L. Stephens. 2009. The efficacy of fire and fuels reduction treatments in a Sierra Nevada pine plantation. International Journal of Wildland Fire 18: 791-801. doi: 10.1071/WF06097

Krebs, C.J. 1999. Ecological methodology. Second edition. Addison-Wesley Educational Publishers, Menlo Park, California, USA.

Kreye, J.K., J.M. Varner, and E.E. Knapp. 2011. Effects of particle fracturing and moisture content on fire behavior in masticated fuel beds burned in a laboratory. International Journal of Wildland Fire 20: 308-317. doi: 10.1071/WF09126

Kreye, J.K., J.M. Varner, and E.E. Knapp. 2012. Moisture desorption in mechanically masticated fuels: effects of particle fracturing and fuel bed compaction. International Journal of Wildland Fire 21: 894-904. doi: 10.1071/WF11077

Kreye J.K., L.N. Kobziar, and W.C. Zipperer. 2013. Effects of fuel load and moisture content on fire behavior and heating in masticated litter-dominated fuels. International Journal of Wildland Fire 22: 440-445. doi: 10.1071/WF12147

Kreye, J.K., N.W. Brewer, P. Morgan, J.M. Varner, A.M.S. Smith, C.M. Hoffman, and R.D. Ottmar. 2014a. Fire behavior in masticated fuels: a review. Forest Ecology and Management 314: 193-207. doi: 10.1016/j.foreco.2013.11.035 
Kreye, J.K., L.N. Kobziar, and J.M. Camp. 2014b. Immediate and short-term response of understory fuels following mechanical mastication in a pine flatwoods site of Florida, USA. Forest Ecology and Management 313: 340-354. doi: 10.1016/j.foreco.2013.10.034

Kreye, J.K., and L.N. Kobziar. 2015. The effect of mastication on surface fire behaviour, fuels consumption and tree mortality in pine flatwoods of Florida, USA. International Journal of Wildland Fire 24: 573-579. doi: 10.1071/WF14186

Parker, V.T., B.R. Pratt, and J.E. Keeley. 2016. Chaparral. Pages 479-507 in: H. Mooney and E. Zavaleta, editors. Ecosystems of California. University of California Press, Oakland, USA.

Potts, J.B., and S.L. Stephens. 2009. Invasive and native plant responses to shrubland fuel reduction: comparing prescribed fire, mastication, and treatment season. Biological Conservation 142: 1657-1664. doi: 10.1016/j.biocon.2009.03.001

Potts, J.B., E. Marino, and S.L. Stephens. 2010. Chaparral shrub recovery after fuel reduction: a comparison of prescribed fire and mastication techniques. Plant Ecology 210: 303-315. doi: 10.1007/s11258-010-9758-1

Rhoades, C.C., M.A. Battaglia, M.E. Rocca, and M.G. Ryan. 2012. Short- and medium-term effects of fuel reduction mulch treatments on soil nitrogen availability in Colorado conifer forests. Forest Ecology and Management 276: 231-238. doi: 10.1016/j.foreco.2012.03.028

Ryan, K.C., E.E. Knapp, and J.M. Varner. 2013. Prescribed fire in North American forests and woodlands: history, current practice, and challenges. Frontiers in Ecology and the Environment 11: e15-e24. doi: 10.1890/120329

Scott, A.C., D.M.J.S. Bowman, W.J. Bond, S.J. Pyne, and M.E. Alexander. 2014. Fire on earth: an introduction. John Wiley \& Sons, Chichester, England, United Kingdom.

Spittler, T.E. 1995. Fire and the debris flow potential of winter storms. Pages 113-120 in: J.E. Keeley and T. Scott, editors. Brushfires in California wildlands: ecology and resource management. International Association of Wildland Fire, Fairfield, Washington, USA.

Stephens, S.L., and J.J. Moghaddas. 2005. Experimental fuel treatment impacts on forest structure, potential fire behavior, and predicted tree mortality in a California mixed conifer forest. Forest Ecology and Management 215: 21-36. doi: 10.1016/j.foreco.2005.03.070

Stephens, S.L., J.D. McIver, R.E.J. Boerner, C.J. Fettig, J.B. Fontaine, B.R. Hartsough, P.L. Kennedy, and D.W. Schwilk. 2012. The effects of forest fuel-reduction treatments in the United States. BioScience 62: 549-560. doi: 10.1525/bio.2012.62.6.6

Vitorelo, B., H.-S. Han, and J.M. Varner. 2009. Masticators for fuel reduction treatment: equipment options, effectiveness, costs, and environmental impacts. In: Environmentally sound forest operations - proceedings of a conference. Council on Forest Engineering, 15-18 June 2009, Lake Tahoe, California, USA.

Wolk, B., and M.E. Rocca. 2009. Thinning and chipping small-diameter ponderosa pine changes understory plant communities on the Colorado Front Range. Forest Ecology and Management 257: 85-95. doi: 10.1016/j.foreco.2008.08.014

Zouhar, K., J.K. Smith, S. Sutherland, and M.L. Brooks. 2008. Wildland fire in ecosystems: fire and nonnative invasive plants. USDA Forest Service General Technical Report RMRS-GTR42-volume 6, Rocky Mountain Research Station, Ogden, Utah, USA. 